\title{
Study of anemia pattern and its correlation with hematological parameters in a tertiary care centre
}

\author{
Revathi Shree $\mathbf{R}^{1}$, Dost Mohamed Khan ${ }^{2, *}$, Naseem $\mathbf{N}^{3}$, Thamarai Selvi ${ }^{4}$, Chandana $\mathrm{A}^{5}$ \\ ${ }^{1,2}$ Associate Professor, ${ }^{3}$ Professor, ${ }^{4,5}$ Assistant Professor, Dept. of Pathology, Shri Sathya Sai Medical College and Research \\ Institute, SBV (Deemed to be University), Kanchipuram, Tamil Nadu, India
}

*Corresponding Author: Dost Mohamed Khan

Email: dostmk@gmail.com

Received: $27^{\text {th }}$ January, 2018

Accepted: $23^{\text {rd }}$ May, 2018

\begin{abstract}
Introduction: WHO defines anemia as decrease in total red blood cell count or haemoglobin level below the normal percentage for that age. Decrease in the haemoglobin results in reduced oxygen delivery to the tissue resulting in hypoxia. The aims and objectives of this study is to detect the prevalence and type of anemia by evaluating the haematological parameters of all the samples that were received.

Materials and Methods: Using EDTA vacutainer tubes, blood samples were collected from inpatients of all age groups. Total RBC count, hemoglobin concentration, packed cell volume and red blood cell indices such as mean corpuscular volume, mean corpuscular haemoglobin, mean corpuscular haemoglobin concentration and red cell distribution width were analysed and correlated with peripheral smear.

Results: Out of 4350 samples, $45.5 \%$ patients were diagnosed as anemic. Microcytic hypochromic blood picture accounts for $48 \%$ which is the predominant type followed by other types such as normocytic anemia, dimorphic smear and macrocytic anemia. Males were commonly affected when compared to females.

Conclusion: Etiopathogenesis of anemia varies according to the age group. The frequency of anemia increases as age advances. Anemia is associated with various conditions such as nutritional deficiency, blood loss, infections and chronic diseases the predominant cause being iron deficiency.
\end{abstract}

Keywords: Anemia, Iron deficiency, Red cell indices, Peripheral smear.

\section{Introduction}

WHO defines anemia as reduction in red blood cell count or haemoglobin level below the normal percentage for that age. ${ }^{1}$ Etiopathogenesis and clinical features varies with different types of anemia. Patients with anemia presents clinically with pallor in the skin and the conjunctiva, syncope, tachycardia and breathlessness. ${ }^{2}$ Iron deficiency is the most common cause of microcytic anemia. Haemoglobin, packed cell volume, transferring saturation and serum ferritin will be reduced with increase in Total Iron binding capacity in Iron deficiency and peripheral smear shows microcytic hypochromic blood picture. ${ }^{3}$ Total Iron binding capacity is reduced with normal or increased serum ferritin with normocytic normochromic blood picture in anemia of chronic disease. ${ }^{4}$ Anemia is more common in developing countries when compared to developed countries. ${ }^{4,5}$ Epithelial cells are mainly affected in iron deficiency resulting in dryness of skin and hair, loss of papillae in tongue leading to atrophic glossitis. ${ }^{5}$ Anemia is classified based on its morphology into microcytic hypochromic, normocytic normochromic and macrocytic anemia. Based on etiology, anemia is classified into nutritional anemia, haemolytic anemia, anemia due to defect in bone marrow and anemia of chronic disease.${ }^{6,7}$ Classification of anemia is done based on the analysis of following parameters: Total RBC count, Hemoglobin, packed cell volume and red cell indices such as mean corpuscular volume, mean corpuscular haemoglobin, mean corpuscular haemoglobin concentration and red cell distribution width. ${ }^{8,9}$ Based on mean corpuscular volume morphological classification of anemia is done and confirmed by peripheral smear. ${ }^{10}$ WHO classification of anemia based on haemoglobin concentration (Table 1). Along with Mean corpuscular volume red cell distribution width is used to differentiate iron deficiency anemia from other anemias. ${ }^{11}$

\section{Materials and Methods}

This study was conducted at Shri Sathya Sai Medical college and Research Institute from January 2017 to May 2017 for a duration of six months. Inpatients of all age groups were included in this study.

Using EDTA vacutainer tubes blood were collected and analysed in the laboratory for haematological parameters using Mindray and Horiba 5 part hematology analyzer. Total Red cell count, hemoglobin concentration and red blood cell indices- Packed cell volume, Mean corpuscular volume, Mean corpuscular hemoglobin, Mean corpuscular haemoglobin concentration and red cell distribution width were evaluated. Based on Mean corpuscular volume morphological classification of anemia is done and confirmed by peripheral smear examination. Using Chi square test statistical analysis was done. 


\section{Results}

Out of 4350 samples, 1980 patients were anemic (Table 2). Among 1980 patients, 1030 (52\%) were male patients and 950(48\%) were female patients (Table 3 ). No statistical difference was observed between two gender. Anemia is most commonly observed in $30-50$ years age (Table 4). According to WHO criteria anemia grading was done. Most common being mild to moderate anemia constituting $41 \%$ and $40 \%$ followed by severe anemia (19\%) (Table 5). Peripheral smear examination done for all the cases. Out of 1980 patients, microcytic hypochromic blood picture was predominant constituting $48 \%$ followed by normocytic normochromic blood picture constituting 39\% and dimorphic smear being $10 \% .3 \%$ cases were macrocytic anemia (Table 6).

Table 1: WHO Criteria of Hemoglobin concentration (gm/dl) for the diagnosis of anemia and severity assessment

\begin{tabular}{|l|c|c|c|}
\hline \multicolumn{1}{|c|}{ Age } & Mild & Moderate & Severe \\
\hline 6 months -5 years & $10-10.9$ & $7-9.9$ & $<7$ \\
\hline 5 -11 years & $11-11.4$ & $8-10.9$ & $<8$ \\
\hline 12-14 years & $11-11.9$ & $8-10.9$ & $<8$ \\
\hline Male $>14$ years & $11-12.9$ & $8-10.9$ & $<8$ \\
\hline Female $>14$ years & $11-11.9$ & $8-10.9$ & $<8$ \\
\hline
\end{tabular}

Table 2: Prevalence of anemia

\begin{tabular}{|l|c|c|}
\hline & Normal subjects & Anemic patients \\
\hline Total Number & 4350 & 1980 \\
\hline Percentage & $100 \%$ & $45.51 \%$ \\
\hline
\end{tabular}

Table 3: Gender distribution of anemic patients

\begin{tabular}{|l|c|c|}
\hline \multicolumn{1}{|c|}{ Gender } & Total Numbers & Percentage \\
\hline Males & 1030 & $52 \%$ \\
\hline Females & 950 & $48 \%$ \\
\hline
\end{tabular}

Table 4: Grading of anemia based on age

\begin{tabular}{|l|c|c|c|c|c|}
\hline $\begin{array}{c}\text { Age in } \\
\text { years }\end{array}$ & $\begin{array}{c}\text { Mild } \\
\text { anemia }\end{array}$ & $\begin{array}{c}\text { Moderate } \\
\text { anemia }\end{array}$ & $\begin{array}{c}\text { Severe } \\
\text { anemia }\end{array}$ & Total & Percentage \\
\hline$>60$ & 115 & 86 & 59 & 260 & $13 \%$ \\
\hline $51-60$ & 156 & 143 & 52 & 351 & $18 \%$ \\
\hline $41-50$ & 184 & 193 & 83 & 460 & $23 \%$ \\
\hline $31-40$ & 162 & 167 & 74 & 403 & $20 \%$ \\
\hline $21-30$ & 103 & 112 & 63 & 278 & $14 \%$ \\
\hline $11-20$ & 66 & 57 & 29 & 152 & $8 \%$ \\
\hline$<10$ & 34 & 28 & 14 & 76 & $4 \%$ \\
\hline
\end{tabular}

Table 5: Grading of anemia

\begin{tabular}{|l|c|c|}
\hline \multicolumn{1}{|c|}{ Anemia Severity } & $\begin{array}{c}\text { Total number of } \\
\text { patients }\end{array}$ & Percentage \\
\hline Mild $(10-12 \mathrm{gm} / \mathrm{dl})$ & 820 & $41 \%$ \\
\hline Moderate $(8-10 \mathrm{gm} / \mathrm{dl})$ & 786 & $40 \%$ \\
\hline Severe $<8 \mathrm{gm} / \mathrm{dl}$ & 374 & $19 \%$ \\
\hline Total & 1980 & $100 \%$ \\
\hline
\end{tabular}

Table 6: Type of anemia based on peripheral smear examination

\begin{tabular}{|l|c|c|}
\hline Peripheral smear examination & Total subjects & Percentage \\
\hline Normocytic normochromic & 774 & $39 \%$ \\
\hline Microcytic hypochromic & 954 & $48 \%$ \\
\hline Macrocytic & 58 & $3 \%$ \\
\hline Dimorphic smear & 194 & $10 \%$ \\
\hline
\end{tabular}




\section{Discussion}

Anemia affects globally with major impact on health of wellbeing. Worldwide around 2.15 billion people are affected by Iron deficiency anemia. 5-10\% dietary iron gets absorbed normally but in iron deficiency the absorption rate increases to three to five times. Decreased intake of vegetables, red meat and fruits found to be associated with iron deficiency. In our study adults were mainly affected by anemia. Predominant being microcytic hypochromic anemia followed by normocytic normochromic anemia and dimorphic smear. Iron deficiency anemia incidence increases in females after menarche. In a study by Pasricha et al, they have found that in rural children microcytic hypochromic blood picture dominates, etiology being iron deficiency. ${ }^{8}$ Iron deficiency during pregnancy is associated with preterm delivery and low birth weight babies. ${ }^{12,13}$ Blood production decreases as age advances with decrease in bone marrow elements and increase in adipose tissue. ${ }^{14}$ In elderly there is ineffective bone marrow response to erythropoietin stimulation. ${ }^{15}$ In elderly identifying the etiology of anemia of chronic disease is challenging as lymphocytes will be seen in any chronic inflammatory pathology. ${ }^{16}$ Red blood cell size is not significantly altered in the elderly, hence based on morphology anemia cannot be classified in the elderly. ${ }^{17} 45.5 \%$ patients were diagnosed as anemic in which $43 \%$ of patients were in the age group of $30-50$ years. Study done by $\mathrm{S}$. Patel et al also showed that anemia was more common in adults. ${ }^{18}$ Anemia in elderly is multifactorial, in which nutritional deficiency is the common cause followed by chronic inflammation, cancer, chronic kidney disease due to diabetes mellitus and hypertension, drugs. ${ }^{19}$ In our study anemia is more prevalent among males (52\%) when compared with females (48\%). This is in concordance to the study done by Olivares et al and kaur et al where they have found males $(37 \%)$ were commonly affected by anemia when compared to females $(33 \%){ }^{20,21}$ In a study by choi et al they have observed that males were more commonly affected with anemia with a incidence of $11.4 \%$ when compared to females $2 \%{ }^{22}$ In our study, microcytic hypochromic blood picture predominates with the incidence of $48 \%$ followed by normocytic blood picture $39 \%$ and dimorphic smear $10 \%$. This is in concordance with the study by Gerado et al. ${ }^{23}$ Normocytic normochromic anemia was predominantly seen in elderly age group. In a study by Korades et al, they have found that children with anemia were having lethargy, difficulty in concentration, irritability and learning difficulty. ${ }^{24}$.

\section{Conclusion}

Based on haematological parameters morphological classification of anemia is done. Iron deficiency is the common cause of microcytic hypochromic blood picture in the young age. Whereas normocytic normochromic anemia is the most prevalent type in adults and elderly, etiology is mutifactorial, due to nutritional deficiency, chronic inflammation, malignancy, drugs and aging process. The presence of anemia need to be evaluated in detail as the etiology is mutifactorial and the cause should be treated. Educational programs and screening programs implementation will help in identifying the high risk and affected groups. Iron fortification of food will help in prevention of Iron deficiency anemia. Iron supplementation to the pregnant and lactating women and growing children will be beneficial as the demand is more in this groups.

\section{References}

1. World Health Organization. Iron deficiency anaemia: assessment, prevention and control. A guide for programme managers. WHO: Geneva; 2001.

2. Lopez A, Cacoub P, Macdougall IC, Peyrin-Biroulet L. Iron deficienc anaemia. Lancet. 2016;387:907-916.

3. Bermejo F, Garcia-Lopez S. A guide to diagnosis of iron deficiency and iron deficiency anemia in digestive diseases. World J Gastroentero. 2009;115:4638-4643.

4. Clark SF. Iron deficiency anemia: diagnosis and management. Curr Opin Gastroenterol. 2009;25:122128.

5. Allen RP, Auerbach S, Bahrain H, Earley J. Prevalence and impact of restless legs syndrome on patients with iron deficiency anemia. Am J Hematol. 2013 ;88:261-64.

6. Ferrucci L, Semba RD, Guralnik JM, Ershler WB, Bandinelli S, Patel KV et al. Proinflammatory state, hepcidin and anemia in older persons. Blood. 2010;115:3810-26.

7. Russell RM, Rasmussen H, Fada RD. The Impact of Nutritional Needs of Older Adults on Recommended Food Intakes. Nutrition in Clinical Care. 1999;2:164-76.

8. S.-R. Pasricha, J. Black, S. Muthayya. Determinants of anemia among young children in rural India, Pediatrics. 2010;126(1):140-49.

9. K. C. Menon, S. A. Skeaff, C. D. Thomson. Concurrent micronutrient deficiencies are prevalent in nonpregnant rural and tribal women from central India. Nutrition. 2011;27(4),496-502.

10. Johnson-Wimbley TD, Graham D. Diagnosis and management of iron deficiency anemia in the $21 \mathrm{st}$ century. Therapeutic Advances in Gastroentesrology. 2011;4:177-184.

11. K. S. Khan, D.Wojdyla, L. Say, A.M. Gulmezoglu, and P. F. van Look. WHO analysis of causes of maternal death: a systematic review. The Lancet. 2006;367(9516):106674.

12. K. Kalaivani. Prevalence \& consequences of anaemia in pregnancy. Indian Journal of Medical Research. 2009;130(5):627-633.

13. L. H. Allen. Anemia and iron deficiency: effects on pregnancy outcome. The American Journal of Clinical Nutrition. 2000;71(5),1280-84.

14. K. Shridhar, P. K. Dhillon, L. Bowen et al. Nutritional profile of Indian vegetarian diets - the Indian Migration Study. Nutrition Journal. 2014;13(55).

15. Z. A. Bhutta, J. K. Das, R. Bahl. Can available interventions end preventable deaths in mothers, newborn babies, and stillbirths, and at what cost?. The Lancet. 2014;384(9940):347-370. 
16. Beutler E, Waalen J. The definition of anemia: what is the lower limit of normal of the blood hemoglobin concentration? Blood. 2006;107,1747.

17. Chaves PH, Xue QL, Guralnik JM. What constitutes normal hemoglobin concentration in community-dwelling disabled older women? J Am Geriatr Soc. 2004;52:1811.

18. S. Patel, M. Shah, J. Patel, N. Kumar. Iron Deficiency anemia in moderate to severely anemic patients. Gujarat Medical Journal. 2009;64(2):15-18.

19. Failace R. Hemograma: manual de interpretação. Porto Alegre: Artmed; 1995. p.197.

20. Olivares M, Hertramp E, Capurro MT, Wegner D. Prevalence of anemia in elderly subjects living at home: role of micronutrient deficiency and inflammation. Eur $J$ Clin Nutr. 2000;54(11):834-9.

21. Kaur H, Piplani S, Madan M. Prevalence of anemia and micronutrient deficiency in elderly. International Journal of Medical and Dental Science. 2014;3(1);296-302.

22. Choi CW, Lee J, Park KH, Yoon SY, Choi IK, Oh SC. Prevalence and Characteristics of Anemia in the Elderly: Cross-Sectional Study of Three Urban Korean Population Samples. Am J Hematol. 2004;77(1):26-30.
23. Gerardo Alvarez Uria, Praveen K. Naik, Manoranjan Midde, Pradeep S. Yalla, Raghavakalyan Pakam, Prevalance and severity of anaemia stratified by age and gender in rural India, Hindawi Publishing Corporation, Anemia. 2014

24. Kordas K, Lopez P, Rosado JL, García Vargas G, Alatorre Rico J, Ronquillo D, Cebrián ME, Stoltzfus RJ. Blood lead, anemia, and short stature are independently associated with cognitive performance in Mexican school children. J Nutr. 2014;134(2):363-371.

How to cite this article: Revathi S.R, Khan D. M, Naseem N, Selvi T, Chandana A. Study of anemia pattern and its correlation with hematological parameters in a tertiary care centre. Indian J Pathol Oncol. 2018;5(4):642-645. 